\title{
OPTIMALISASI PEMANFAATAN ASET TANAH DAN BANGUNAN MILIK PEMERINTAH KOTA BANDA ACEH
}

\author{
Fadillah Ibrahim ${ }^{1}$, Ridwan $^{* 2}$ \\ ${ }^{1,2}$ Program Studi Akuntansi Fakultas Ekonomi Universitas Syiah Kuala \\ e-mail: Ibrahimfadil706@gmail.com ${ }^{1}$, ridwan.ibrahim@unsyiah.ac.id ${ }^{* 2}$
}

\section{* Corresponding Author}

\begin{abstract}
This research aims to identify and analyze the optimization of the utilization of land and building assets belonging to the Banda Aceh City Government, especially in market buildings to increase local revenue. Research on the optimization of the use of land and building assets owned by the Banda Aceh City Government uses a qualitative descriptive approach, the data used are secondary data in the form of financial reports in the Banda Aceh City Government during 2015-2018, and also primary data using interview techniques. The results of this study indicate that the contribution rate of asset utilization from 2015-2018 is still not optimal for increasing PAD and below 1\% with an average of $0.045 \%$. Meanwhile, the level of contribution to the market retribution services is still not optimal for increasing PAD. seen the contribution of the realization of market service levies to local revenue in 2015 amounted to $0.092 \%$. 2016 The contribution of realization of market service fees was $0.083 \%$ Likewise in 2017, the contribution of market retribution of services was the same as in 2016, namely 0.083\%. However, in 2018, the contribution to the realization of market services was higher than the previous year, the amounting to $0.094 \%$.
\end{abstract}

Keywords: Optimization, Assets, Asset Utilization, Government

\section{Pendahuluan}

Pendapatan Asli Daerah merupakan pendapatan daerah yang bersumber dari hasil pajak daerah, hasil pengelolaan kekayaan daerah yang dipisahkan dan lain-lain pendapatan Asli Daerah yang sah untuk bertujuan melaksanakan otonomi daerah sebagai perwujudan asas desentralisasi.Pemerintah Daerah dituntut memiliki suatu kemandirian memiliki dalam membiayai sebagian besar pembangunannya. Oleh Sebab itu, Pemerintah Daerah harus memanfaatkan sumber daya yang ada secara berdaya guna serta mampu mengoptimalkan sumber-sumber penerimaan daerah termasuk pengoptimalan aset-aset yang ada.

Aset daerah adalah semua barang berwujud maupun tidak berwujud milik Daerah yang berasal dari pembelian dengan dana yang bersumber seluruhnya atau sebagian dari APBD, dan atau perolehan lainnya yang sah (Kepmendagri No.29 Tahun 2002 Bab I pasal 1). Aset daerah merupakan harta kekayaan daerah yang terdiri dari barang bergerak dan tidak bergerak yang dikuasai,dimiliki oleh Pemerintah Daerah yang seluruhnya atau sebagian di biayai dengan dana anggaran dan belanja daerah.
Tanah dan bangunan merupakan bentuk aset tidak bergerak. Pemanfaatan aset daerah khususnya tanah dan bangunan yang optimal akan mendorong pertumbuhan ekonomi yang akan berdampak pada peningkatan Pendapatan Asli Daerah (PAD) sebagai sumber pembiayaan daerah.Sebaliknya, aset daerah yang tidak dikelola dengan optimal, akan memboroskan keuangan daerah melalui pembiayaan pemeliharaan aset yang tidak sepadan dengan manfaat atau keuntungan yang dihasilkan.

\section{Kajian Pustaka}

\section{Aset/Barang Milik Daerah}

Aset/Barang milik daerah adalah barang yang bersumber dari pembentukan daerah otonom berdasarkan undang-undang, pembelanjaan APBN/APBD, sumbangan dalam/luar negeri, sumbangan pihak ke tiga, penyerahan dari pemerintah pusat, fasilitas sosial dan fasilitas umum, swadaya masyarakat, semua barang yang secara hukum dikuasai pemerintah daerah sebagaimana disebut dalam Peraturan Menteri Dalam Negeri Nomor 17 Tahun 2007 bahwa semua kekayaan 
daerah baik yang bergerak maupun yang tidak bergerak beserta bagian- bagiannya ataupun yang merupakan satuan tertentu yang dapat dinilai, dihitung, diukur, atau ditimbang termasuk hewan dan tumbuh-tumbuhan kecuali uang dan surat-surat berharga lainnya.

Menurut Peraturan Menteri Dalam Negeri Nomor 19 Tahun 2016 Bahwa Pengelolaan Barang Milik Daerah merupakan keseluruhan kegiatan yang di dalamnya meliputi perencanaan kebutuhan dan penganggaran, pengadaan, penggunaan, pemanfaatan, pengamanan dan pemeliharaan, penilaian, pemindahtanganan, pemusnahan, penghapusan, penatausahaan dan pembinaan, pengawasan dan pengendalian.

\section{Pengertian Optimalisasi Aset}

Pengertian Optimalisasi menurut Kamus Besar Bahasa Indonesia (2008, p 986), Optimalisasi adalah proses, cara dan perbuatan untuk mengoptimalkan atau menjadikan paling baik, paling tinggi, dsb. Sedangkan dalam kamus Oxford (2008, p. 358) Optimization is the process of finding the best solutionto some problem where "best" accords to prestated criteria Jadi, Optimalisasi adalah sebuah proses, cara dan perbuatan (aktivitas/kegiatan) untuk mencari solusi terbaik dalam beberapa masalah, dimana yang terbaik sesuai dengan kriteria tertentu. Optimalisasi aset adalah proses kerja dalam pengelolaan aset yang dimiliki seseorang atau perusahaan.

\section{Bentuk Pemanfaatan Aset}

Pemanfaatan Aset dilakukan dengan ketentuan Berdasarkan Peraturan Menteri No.19 tahun 2016 tentang pengelolaan barang daerah, bentuk pemanfaatan aset milik daerah berupa : sewa, pinjam pakai, kerja sama pemanfaatan,bangunan serah guna, bangunan guna serah dan kerja sama infrastruktur. Penjelasan bagaimana bentuk-bentuk pemanfaatan aset disebutkan yaitu :

1) Sewa

Pengertian menurut Peraturan Pemerintah Nomor 27 Tahun 2014 Tentang Pengelolaan Barang Milik Daerah adalah pemanfaatan Barang milik Daerah/Negara oleh pihak Lain dalam jangka waktu tertentu dan menerima imbalan uang
tunai.Sewa merupakan salah satu bentuk pemanfaatan Brang milik Negara/Daerah. Sewa dapat dilakukan terhadap barang milik Negara/Daerah asal barang tersebut tidak digunakan dan dengan mengubah status kepemilikkan terhadap barang tersebut.

2) Pinjam Pakai

Pinjam Pakai menurut pengertian dari Peraturan Pemerintah pasal 1 Nomor 27 Tahun 2014 adalah penggunan barang antara pemerintah pusatdan Pemerintah Daerah atau antar Pemerintah Daerah dalam jangka waktu tertentu tanpa menerima imbalan dan setelah jangka waktu tertentu berakhir diserahkan kembali kepada pengelola barang.

3) Kerja Sama Pemanfaatan

Kerja Sama Pemanfaatan adalah Pendayagunaan BMN/BMD oleh pihak lain dalam jangka waktu tertentu dalam rangka peingkatan penerimaan Negara bukan pajak/pendapatan daerah dan sumber pendapatan lainnya.

4) Bangun Guna Serah Atau Bangun Serah Guna

Bangun Guna Serah adalah adalah pemanfaatan BMN/D berupa tanah oleh pihak lain dengan cara mendirikan bangunan dan/atau sarana berikut fasilitasnya, kemudian didayagunakan oleh pihak lain tersebut dalam jangka waktu tertentu yang telah disepakati, untuk selanjutnya diserahkan kembali tanah berikut fasilitasnya setelah berakhirnya jangka waktu.

Bangunan Serah Guna adalah pemanfaatan BMN/D berupa tanah oleh pihak lain dengan cara mendirikan bangunan atau sarana berkut fasilitasnya dan setelah selesai pembangunanya diserahkan untuk didayagunakan oleh pihak lain tersebut dala jangka waktu tertentu

5) Kerja Sama Penyediaan Infrakstruktur

Kerja Sama Penyediaan Infrastruktur adalah kerja sama antara Pemerintah dan Badan Usaha untuk kegiatan penyediaan infrastruktur dengan ketentuan peraturan perundang-undangan

\section{Metodologi Penelitia Desain Penelitian}

Desain penelitian merupakan kerangka penelitian untuk menjawab pertanyaan penelitian dengan melakukan pengumpulan, pengukuran, dan 
analisis data. Desain penelitian memiliki kaitan dengan pengambilan keputusan perihal tujuan penelitian, jenis penelitian, tingkat intervensi penelitian, situasi studi, unit analisis dan horizon waktu (Sekaran \& Bougie, 2016). Desain penelitian pada penelitian ini akan dijelaskan sebagai berikut:

1. Tujuan Penelitian

Penelitian ini bermaksud untuk mengetahui pengaruh inventarisasi aset, legal audit aset dan penilaian aset terhadap optimalisasi manajemen aset pemerintah Kota Banda aceh serta mengetahui Optimalisasi dalam pengelolaan aset daerah Pemerintah Kota Banda Aceh.

2. Jenis penelitian

Pada penelitian ini menggunaka metode deskriptif Kualitatif. Metode penelitian kualitatif merupakan metode penelitian yang berfungsi untuk mengamati objek secara alamiah. Peneliti berperan sebagai instrumen penelitian dengan melakukan teknik wawancara dengan analisis data yang bersifat induktif. (Sugiono, 2010).

Pada penelitian ini, jenis pendekatan penelitian yang digunakan adalah pendekatan Kualitatif deskriptif. Pendekatan Kualitatif deskriptif merupakan suatu penelitian yang menjelaskan dan menggambarkan keadaan nyata objek penelitian sehingga bersifat menjelaskan fenomena yang terjadi. Hasil penelitian ini harus menjelaskan gambaran secara objektif mengenai keadaan objek penelitian yang sebenarnya (Moleong, 2013).

3. Situasi Penelitian

Situasi penelitian yang digunakan peneliti yaitu dengan menggunakan situasi yang diatur, dengan melakukan perjanjian untuk melakukan wawancara dengan kabid Aset dan Staf Khusus aset Pemerintah Kota dan juga akan melakukan dokumentasi.

4. Unit analisis

Unit analisis yang digunakan dalam penelitian terbagi menjadi lima tingkatan, yaitu individu, kelompok, organisasi, interaksi sosial, dan artefak sosial (Morissan, 2014). Dalam penelitian ini, unit analisis yang akan digunakan adalah tingkat Lembaga pemerintahan, yaitu Badan Pengelolaan Keuangan Kota bidang aset

\section{Sumber dan Teknik Pengumpulan Data}

Penelitian ini menggunakan Teknik pengumpulan data melalui wawancara. Wawancara merupakan percakapan yang dilaksanakan oleh dua pihak, yaitu pihak pewawancara (interviewer) yang mengajukan pertanyaan terkait informasi yang ingin diketahui dan narasumber (interviewee) yang memberi respon atas pertanyaan yang diajukan interviewer (Moleong, 2013). Wawancara yang digunakan dalam penelitian ini merupakan wawancara semi terstruktur. Peneliti menyusun daftar pertanyaan dan memungkinkan adanya pertanyaan baru sesuai dengan respon dari narasumber.

Adapun yang akan peneliti tanyakan kepada informan meliputi aspek-aspek dalam pemanfaatan aset khususnya pemanfaatan aset pada bangunan pasar.

\section{Metode Analisis Data}

Metode penelitian yang digunakan dalam penelitian ini adalah deskriptif kualitatif. Penelitian deskriptif merupakan metode yang digunakan untuk menggambarkan atau menganalisis suatu hasil penelitian tetapi tidak digunakan untuk membuat kesimpulan yang lebih luas (Sugiyono, 2014)

Langkah-langkah yang harus dilakukan dalam rencana penelitian ini yaitu:

1) Studi Pustaka

Teknik studi dokumen yaitu dengan mengkaji dokumen-dokumen baik berupa buku referensi maupun peraturan atau pasal yang berhubungan dengan penelitian yang sedang dilakukan. Telaah dokumen yang berkaitan dengan jalan melakukan penelusuran terhadap beberapa dokumen yang berkaitan dengan objek penelitian guna mendapatkan data sekunder yang akan digunakan dalam menganalisis permaslahan, yaitu yang berhubungan dengan teori-teori, undang-undang dan dokumen tentang optimalisasi pengelolaan aset.

2) Wawancara

Teknik ini digunakan untuk mendapatkan informasi dari informan secara jelas dan mendalam tentang berbagai aspek yang diperlukan. Wawancara sangat diperlukan untuk mendalami berbagai interprestasi, presepsi, dan prespektif berbagai kebijakan sehubungan dengan permasalahan penelitian. Penelitian ini 
mengumpulkan informasi melalui wawancara terhadap penelitian yang dilakukan agar mendapatkan sumber data yang diharapkan. Informasi yang ingin didapatkan dari wawancara ini mengenai aset yang ada di Kota Banda Aceh apakah sudah Optimal dalam mendukung pelayanan kepada masyarakat, sudah Optimal Bagi Pemasukkan Daerah,dan sudah berfungsi semestinya. Demikian juga masalah inventarisasi aset sebagaimana hingga sekarang belum data yang kongkrit tentang jumlah pemetaan aset yang dimilki pemerintah kota Banda Aceh juga termasuk legal Audit yang minta. Selanjutnya. Wawancara ini juga untuk melihat penilaian independen (sertifikasi) terhadap aset tetap tanah dan Bangunan milik pemerintah Kota Banda Aceh.

\section{Hasil Penelitian dan Pembahasan}

\section{Profil Badan Pengelola Keuangan Banda Aceh}

Badan Pengelolaan Keuangan Kota Banda Aceh merupakan bagian dari pendukung tugas Pemerintah Kota Banda Aceh di bidang pengelolaan keuangan. Badan Pengelola keuangan Kota Banda Aceh Melakukan tugas umum pemerintahan di bidang Pendataan, Penagihan, Anggaran, Perbendaharaan, Akuntansi dan Pelaporan Keuangan, serta Aset sesuai dengan Perundang-undangan, di bawah dan dipertanggungjawab kepada Walikota.

Badan Pengelola Keuangan Kota Banda Aceh seuai pada qanun/perda Banda Aceh No 1 Tahun 2007 pasal 2 mengatakan Walikota selaku kepala Pemerintah Kota Banda Aceh adalah pemegang kekuasaan pengelolaan keuangan daerah dan mewakili Pemerintah Kota Banda Aceh dalam kepemilikan kekayaan daerah yang dipisahkan. Badan Pengelolaan Keuangan Kota Banda Aceh memiliki tugas pokok untuk membantu Walikota untuk menyusun kebijakan dan mengkoordinasikan penyelenggaraan urusan pemerintahan daerah termasuk pengelolaan keuangan daerah.

\section{Aset Tetap dan Bangunan Milik Kota Banda Aceh}

Nilai Barang Milik Daerah 2019 diperoleh berdasarkan realisasi pelaksanaan dan kegiatan anggaran tahun 2019 yang turut mempengaruhi secara siginifikan terhadap jumlah dan nilai Barang Milik
Daerah. Nilai Barang Daerah setelah dikeluarkannya barang ekstrakomptabel dan nilai penyusutan, sehingga nilai aset Kota Banda Aceh Tahun 2019 sebagai berikut :

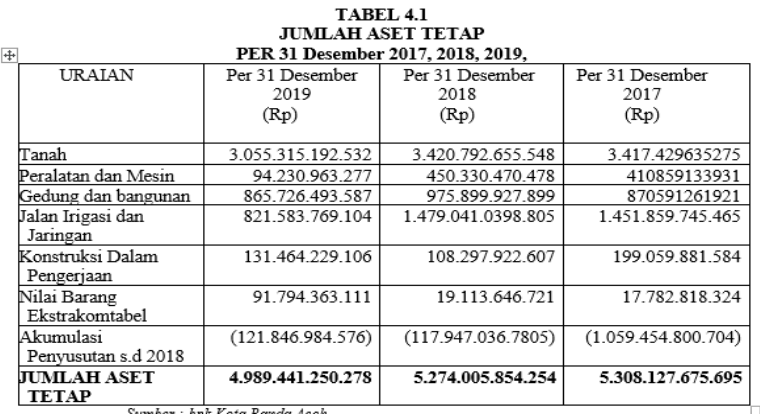

Sumber: Data diolah (2020)

Tahun 2019 Jumlah Aset Tanah Milik Pemerintah Kota Banda Aceh dengan nominal Rp.3.055.315.192.532. Sedangkan pada tahun 2018 Jumlah Aset Tanah sebesar Rp. 3.420.792.655.548 dan pada tahun 2017 Aset Tanah MIlik Pemerintah Kota Banda Aceh sebesar Rp. 3.417.429635275 yang tersebar diseluruh kota Banda Aceh dan Aceh besar (rincian terlampir). Sedangkan untuk bangunan, berjumlah 865.726.493.587 yang juga tersebar di seluruh kota Banda Aceh dan Aceh besar.Total Aset tetap Kota Banda Aceh pada tahun 2019 berjumlah Rp 4.989.441.250.278 yang sudah dilakukan audit oleh BPK.

\section{Potensi Retribusi Pasar}

Retribusi Pelayanan Pasar merupakan jenis retribusi yang masuk kedalam kelompok retribusi jasa umum dan berdasarkan peraturan Walikota Nomor 20 Tahun 2019 tentang tariff sewa aset pasar dan jasa layanan badan layanan umum menyatakan, Tarif sewa aset dan jasa layanan adalah sebagian atau seluruh biaya penyelenggaraan kegiatan pelayanan di BLUD UPTD pasar yang dibebankan kepada masyarakat sebagai pengguna jasa pelayanan.

Besar biaya dari sewa bangunan pasar berbeda sesuai tipe bangunan, jenis pelayanan yang diberikan dan luas tempat berjualan, dan jenis fasilitas yang digunakan. Pembayaran sewa dipungut setiap hari dengan menggunakan surat ketetapan tarif dan apabila tidak mampu secara tunai dan lunas penyewa dapat diperkenankan untuk membayar secara bulanan yang telah dicanumkan dalam perjanjian sewa menyewa. 
Berdasarkan regulasi inilah maka aset daerah dalam bentuk pasar merupakan salah satu penerimaan PAD.

Adapun tarif yang dikenakan untuk fasilitas kios dan toko permanen adalah Rp 2000/hari.

Tabel 4.2

Potensi Retribusi Pasar dalam setahun

di Kota Banda Aceh Tahun 2019

\begin{tabular}{|l|r|r|r|r|}
\hline Pasar & Jumlah & \multicolumn{1}{|c|}{ Tarif } & \multicolumn{1}{|c|}{ Frekuensi } & \multicolumn{1}{l|}{ Jumlah } \\
unit & (Rp) & \multicolumn{1}{c|}{ Bayar } & \multicolumn{1}{c|}{ (Rp) } \\
\hline $\begin{array}{l}\text { Pasar } \\
\text { Atjeh }\end{array}$ & 649 & 2,000 & 360 & $467,280,000$ \\
\hline $\begin{array}{l}\text { Pasar } \\
\text { Kartini }\end{array}$ & 52 & 2,000 & 360 & $37,440,000$ \\
\hline $\begin{array}{l}\text { Pasar } \\
\text { Rex }\end{array}$ & 25 & 10,000 & 360 & $90,000,000$ \\
\hline $\begin{array}{l}\text { Pasar } \\
\text { KpBaru }\end{array}$ & 66 & 2,000 & 360 & $47,520,000$ \\
\hline Jumlah & 792 & & & $1,069,920,000$
\end{tabular}

Sumber: Data diolah (2020)

Berdasarkan hasil analisis potensi diketahui bahwa untuk pasar Atjeh potensi penerimaan retribusi berdasarkan Jumlah unit diperoleh Nilai Sebesar Rp 467.280.000,- yang berasal dari 649 unit Toko Yang ada. Untuk Pasar Kartini Potensi penerimaan nya adalah sebesar Rp. 37.440.000 Dengan Fasilitas sebanyak 52 unit. Untuk pasar Kampung Baru potensi penerimaan retribusi senilai Rp. 47,520,000 yang berasal dari 66 jumlah unit toko yang ada dalam setahun. Kondisi ini dapat diperoleh apabila aktivitas pasa dapat berjalan optimal dan pemungutannya juga optimal.

\section{Kontribusi Pelayanan Pasar}

Retribusi pelayanan pasar adalah pungutan sebagai pembayaran atas penyediaan jasa.perizinan di bidang perpasaran oleh Pemerintah Daerah untuk kepentingan pribadi atau badan. Objek Retribusi pasar adalah penyediaan pelatran los,kios yang dikelola Pemerintah Daerah dan khusus disediakan untuk pedagang. Kontribusi dalam penelitian ini dapat diartikan sebagai sumbangan yang diberikan Retribusi Pelayanan pasar terhadap Pendaopatan Asli Daerah.

Tabel 4.3

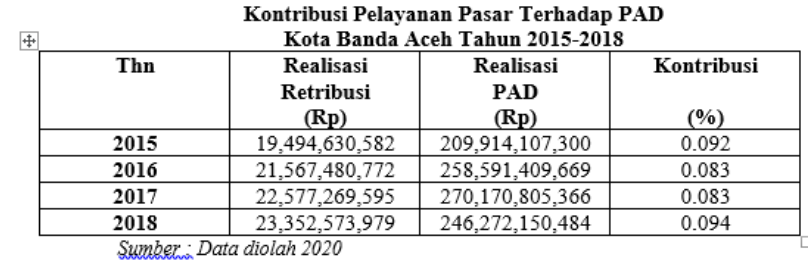

Sumber: Data diolah (2020)
Berdasarkan tabel diatas, realisasi retribusi pelayanan pasar masih belum optimal untuk meningkatkan PAD. Ini dapat dilihat kontribusi realisasi retribusi pelayanan pasar terhadap pendapatan asli daerah tahun 2015 sebsar $0.092 \%$ yang dieperoleh dari realisasi anggaran retribusi pelayanan pasar sebesar Rp.19,494,630,582. Tahun 2016 Kontribusi realisasi retribusi pelayan pasar sebesar $0.083 \%$ dari realisasi anggaran retribusi pelayanan pasar sebesar Rp.21,567,480,772. Begitu pula pada tahun 2017, kontribusi pelayanan retribusi pasar sama dengan Tahun 2016 yaitu $0.083 \%$. Namun pada Tahun 2018, Kontribusi realisasi pelayanan pasar lebih tinggi dari tahun sebelumnya yaitu sebesar $0.094 \%$ dari realisasi anggaran retribusi pasar sebesar Rp.23,352,573,979.

Melihat hasil persentase kontribusi realisasi pelayanan pasar terhadap PAD dari Tahun 2015-2018 dapat disimpulkan bahwa persentase hasilnya masih di bawah $1 \%$. Hal ini disebabkan oleh biaya operasional pasar yang cukup tinggi dan pengelolaan retribusi pasar serta pemanfaatan aset pasar masih belum optimal dijalankan.

\section{Kontribusi Tahunan Bentuk Pemanfaatan Bangun Serah Guna (BSG)}

Pelaksanaan pemanfaatan aset tanah dan bangunan dalam bentuk Bangun Guna Serah dan Bangun Guna Serah di Pemerintah Kota Banda Aceh sudah dilaksanakan dengan baik sesuai dengan permendagri tahun 2016. Pemanfaatan bangunan dalam bentuk bangun serah guna adalah SUZUYA MALL yang terdapat di jalan Teuku Umar Seutui Banda Aceh. Bangunan tersebut dibangun di atas tanah milik Pemerintah Kota Banda Aceh dan dalam jangka waktu tertentu bangunan beserta tanah tersebut akan diserahkan kembali kepada Pemerintah Kota Banda Aceh untuk dikelola.

Jangka waktu pemakaian tanah dan bangunan SUZUYA MALL selama 30 tahun terhitung mulai dari tahun 2012-2042 sesuai kontrak yang telah disepakati oleh pihak Pemerintah Kota Banda Aceh melalui Walikota Banda Aceh saat itu bapak Mawardy Nurdin dan juga pihak PT.Suriatana Mahkota Kencana selaku perusahaan yang memiliki Suzuya Mall. Selama belum habis masa pemakaian, Pihak SUZUYA MALL membayar dana Kontribusi Tetap setiap tahunnya. 
Pendapatan Pemerintah dari pemanfaatan dalam bentuk bangun serah guna ditentukan berdasarkan perkalian persentase kontribusi tetap dengan nilai wajar aset seperti berikut :

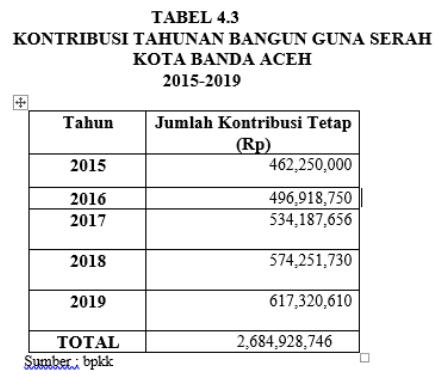

Sumber: Data diolah (2020)

\section{Kontribusi Pemanfaatan Aset}

Kontribusi adalah perbandingan (rasio) Pendapatan Asli Daerah pertahun dengan Hasil pemanfaatan aset yang dipisahkan dalam satuan persentase sebagai berikut.

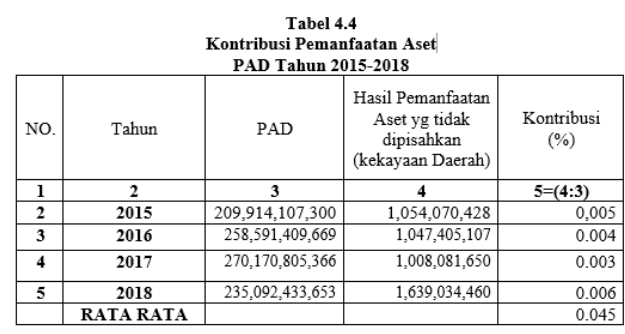

Sumber: Data diolah (2020)

Dari tabel diatas dapat diketahui bahwa tingkat Kontribusi pemanfaatan aset terhadap PAD pada Tahun 2015-2018 rata-rata sebesar 0.045 . Angka tersebut menunjukkan bahwa kontribusi pemanfaatan aset terhadap PAD Kota Banda Aceh tahun 2015-2018 dan masih belum optimal, hasilnya masih dibawah $1 \%$. Pada Tahun 2015 angka kontribusi pemanfaatan aset sebsear 0,005 dan realisasi PAD sebesar Rp209,914,107,300. .Pada Tahun 2016 angka kontribusi pemanfaatan aset sebesar 0.004 dan PAD sebesar Rp 258,591,409,669. Tahun 2017 angka Kontribusi yaitu 0.003 dengan PAD sebesar Rp 270,170,805,366. Tahun 2018 kontribusi pemanfaatan aset sebesar 0.006 dengan PAD Rp 235,092,433,653.

Faktor yang Menghambat Pemanfaatan Aset Tanah dan Bangunan Pemerintah Kota Banda Aceh

Pemanfaatan Aset tanah dan bangunan yang kurang baik akan menjadi hambatan bagi Pemerintah
Kota Banda Aceh untuk meningkatkan PAD. Mengindentifikasi penyebab yang menjadi hambatan dalam pemanfaatan aset tanah dan Bangunan khususnya pasar yang dapat dimanfaatkan secara optimal. Yang menjadi hambatan dalam pemanfaatan aset tanah dan bangunan adalah pemeliharaan aset dan terkesan terbengkalai dan dibiarkan begitu saja dan masih ada fasilitas pasar yang tidak difungsikan sebagaimana mestinya oleh pemilik fasilitas sewa pasar terutama kios. Masih ada petugas pemungut baik retribusi pasar yang melakukan pungutan tanpa memberikan karcis. Masih banyak pedagang yang tidak membayar sesuai dengan fasilitas yang digunakan.

\section{Hasil dari Optimalisasi Pemanfaatan Aset Tanah dan Bangunan}

Hasil Tahapan dalam Optimalisasi pemanfaatan adalah masyarakat dapat memanfaatkan aset milik Pemerintah Kota Banda Aceh dengan lebih nyaman dan merasa senang jika pemanfaatan aset dikelola dengan baik Oleh Pemerintah Kota Banda Aceh dan akan meningkatkan PAD namun sebaliknya, jika pemanfaatan Tidak dijalankan secara optimal, maka masyarakat merasa tidak nyaman dan enggan untuk memanfaatkan pasar tersebut dan akan mengurangi PAD.

\section{Kesimpulan dan Saran}

\section{Kesimpulan} bahwa :

Dari pembahasan diatas dapat disimpulkan

1. Tingkat Kontribusi pemanfaatan aset Kota Banda Aceh masuk dalam kategori belum Optimal Angka Tingkat kontribusi tahun 2015-2018 masih berada dibawah $1 \%$ dengan rata-rata $0.045 \%$. Retribusi Pelayanan pasar belum Optimal untuk meningkatkan PAD, tingkat kontribusi 2015-2018 juga dibawah $1 \%$.

2. Kendala yang menjadi penghambat tidak berjalannya optimalisasi pemanfaatanya adalah pemeliharaan aset dan terkesan terbengkalai dan dibiarkan begitu saja fasilitas pasar yang tidak difungsikan sebagaimana mestinya oleh pemilik fasilitas sewa pasar terutama kios. Masih ada petugas pemungut baik retribusi pasar yang melakukan pungutan tanpa memberikan karcis. 
Masih banyak pedagang yang tidak membayar sesuai dengan fasilitas yang digunakan

3. Bentuk Pemanfaatan Aset tanah dan bangunan milik Pemerintah Kota Banda Aceh berupa sewa, bangun guna serah dan bangun serah guna

4. Hasil dari pemanfaatan aset tanah dan bangunan mili pemerintah Kota Banda Aceh adalah bisa lebih meningkatkan PAD dan juga meningkatkan daya beli ekonomi masyarakat Kota Banda Aceh.

\section{Saran akademis}

Untuk selanjutnya agar dapat memperluas penelitian tentang optimalisasi pemanfaatan aset tanah dan bangunan yang lainya, selanjutnya peneliti akan menggunakan dan menambahkan pengumpulan data lainnya agar lebih akurat.

\section{Saran Praktis}

Tanah dan Bangunan Pemerintah Kota Banda Aceh perlu dikelola dengan lebih baik dan memberikan manfaat bagi pihak pengelola dan pengguna Bangunan maupun bagi masyarakat sekitar. Sedangkan pada bangunan yang belum atau sedang tidak ada penggunaan di atasnya maka harus di lakukan upaya pemanfaatn seperti melakukan kerjasama dengan pihak lain agar memberi manfaat.

Pemanfaatan tanah dan Bangunan diharapkan dapat mengoptimalkan potensi aset daerah, menjaga, mendukung pengamanan, memberi manfaat yang lebih, baik bagi pihak pengelola, pengguna tanah aset maupun manfaat bagi masyarakat seiktar tanah dan bangunan tersebut berada.

\section{Daftar Pustaka}

Riyono Sugeng. (2013). Pemanfaatan Aset Daerah. Jurnal Administrasi Publik, Volume 11, Nomor 2, Desember 2013

Runiawat, N. (2012).Pemanfaatan Barang Milik Daerah.Dosen Administrasi Publi Universitas Padjajaran, Bandung.

Sundari, M., Ma'rif, S. (2013). Optimalisasi Pemanfaatan Tanah Aset Pemerintah Kota Semaranag di Kecamatan Banyumanik. Jurnal pembangunan wilayah dan kota, Vol 19.Jawa Tengah

Hanis, H., M., Trigursyah, B., and Susilawati, C, 2011. The Application Of Public Asset Management in
Indonesian Local Government. Quennsland University of Technology, Brisbane, Australia.

Republik Indonesia (2016). Peraturan Menteri Dalam

Negeri tentang Pedoman Pengelolaan Barang Milik Daerah Pernyataan Standar Akuntansi Pemerintah Nomor 07 Tentang Aset Tetap

Pemerintah Kota Banda Aceh. Peraturan Walikota Banda Aceh Nomor 20 Tahun 2019 . tentang Tarif Sewa Aset pasar dan Jasa Layanan Pada Badan Layanan Umum Daerah.

Pemerintah Kota Banda Aceh. Qanun Nomor 7 Tahun 2019. Tentang Pengelolaan Barang Milik Daerah

Pemerintah Kota Banda Aceh.PeraturanWalikota No.21. Tentang Kebijakan Akuntansi Pemerintah Daerah Banda Aceh.KBA.ONE

Republik Indonesia. (2014). Peraturan Pemerintah Republik Indonesia Nomor 27 tentang Pengelolaan Barang Milik Negara/Daerah.

2014. Undang-Undang RI No. 23 Tentang pemerintah daerah.

Sugiyono. (2013). Metode Penelitian Manajamen. Penerbit Alfabeta, Bandung.

Siregar, Doli D. (2004). Manajemen Aset (Strategi Penataan Konsep Pembangun Berkelanjutan Secara Nasional Dalam Konteks Kepala Daerah 